Original Article

\title{
Effect of homeopathic medication on the cognitive and motor performance of autistic children (Pilot study)
}

\author{
Geórgia Regina Macedo de Menezes Fonseca루 Fábio de Almeida Bolognani¹; \\ Fabiane Ferreira Durãoํㅜㄹ Krishna Maio Souza ${ }^{1}$; Mônica de Castro e Costa \\ Accioly2; Maria Fernanda Bagarollo ${ }^{3}$
}
${ }^{1}$ Brazilian Federation of Homeopathy, Outpatient Clinic of Neurological and Development Diseases, RJ, Brazil; 2 "Mão Amiga" Association for Support of Autistic Individuals, RJ, Brazil; ${ }^{3}$ Children and Adolescent Health Program, State University of Campinas - UNICAMP, SP, Brazil.

\begin{abstract}
Autism is an infantile disorder of development characterized by deficits in social interaction, communication and unusual and repetitive behavior. Diagnosis is essentially grounded on behavioral tests and there is no pharmacological specific treatment, treatment is merely symptomatic. The aim of this study is to demonstrate the effect of homeopathic remedies on the cognitive and motor development in children with infantile autism. It is presented the evolution of 7 out of 30 children that already were evaluated twice with Psychoeducational Profile Revised (PEP-R), the first was performed before and the second 4-10 months after the onset of homeopathic treatment. Remedies were selected according to similarity between pathogenetic and repertory data and the general symptoms of autism, as well as specific individualization of symptoms in each case, and included organotherapics chosen according to studies related to the brain areas affected by autism. Results showed a positive interference of homeopathic treatment on development and behavior. These results encourage us to continue the study with a larger number of patients.
\end{abstract}

Keywords: Autism; Homeopathy; Cognitive skills; Motor skills.

\section{Introduction}

Autism is a deficiency that groups together a wide scope of disturbs sharing common characteristics, but which are manifested in different ways in each individual. Characteristic traits are disturbs in social interaction, language and behavior. The level of autism varies continuously from weak to severe, in interaction with the general intelligence level, which also varies from severe additional learning disabilities to normal patterns and in some rare cases, intelligence levels bordering genius [1].

Although a precise cause has not yet been established, recent studies suggest a biological origin, genetically based, affecting the development of the brain. In spite of scientific advance, diagnosis remains exclusively clinical, grounded on behavioral tests and the criteria listed in the International Statistical Classification of Diseases and Related Health Problems - ICD-10 [2] and the $4^{\text {th }}$ edition of the Diagnostic and Statistic Manual of Mental Disorders - DSM-IV [3].

Different hypothesis on the cause of autism lead to several therapeutic approaches. However, current knowledge and resources are still insufficient to elaborate a therapeutic drug protocol taking into account the real symptoms of autism. The present study was designed to evaluate the effect of homeopathic treatment on the cognitive and motor disturbs, through a validated specific instrument, Psychoeducational Profile Revised - PEP-R [4-6]. 
PEP-R includes an inventory of behaviors and abilities conceived to identify irregular and idiosyncratic learning patterns. It is more frequently used in children age 6 months to 7 years, but it can also be used in older children, provided alphabetization is not complete. PEP-R supplies data on development, through: imitation, perception, fine motor skills, gross motor skills, eyehand coordination, cognitive performance and cognitive verbal performance. The test also identifies behavioral disturbs in relationship and affect area, play, interest in materials, sensorial responses and language.

\section{Materials and Methods}

The study population included children of both genders, $\mathrm{n}=30$, seen at the Outpatient Clinic for Neurological and Development Disease of the Brazilian Federation of Homeopathy, Rio de Janeiro, Brazil, a nonprofit institution, with a diagnosis of autism made according to DSM-IV criteria. Exclusion criteria included: children older than 7 years old that had already completed alphabetization and patients that initiated other therapeutic modalities after the onset of the homeopathic treatment.

PEP-R was applied by the same psychologist or speech therapist in identical environmental conditions and presentation of materials in both tests.

Homeopathic remedies were chosen by similarity to the common and individualized symptoms of the patients. Remedies were prescribed single or in combination, according to the symptoms of each patient. The remedies used were: Carcinosinum, Stramonium, Natrium muriaticum, Arnica, Arsenicum album and Thebaicum. Dilutions were selected according to the degree of similarity between the pathological and pathogenetic symptoms, varying between $30-200 \mathrm{cH}$.

The therapeutic scheme was completed with organotherapics (originated from sheep tissues, produced by Dolisos/Boiron Laboratories - France), a modality of isopathic treatment grounded on the use of diluted and agitated homologous human body tissues in order to correct dysfunctions. They aim to act directly on the affected tissue, equilibrating its deregulated function, through stimulation or reduction, according to the dilution employed (low: stimulating; middle: regulatory; high: depressant). According to Tetau, organotherapy, when integrated to homeopathic therapy amplifies the mode of action and the field of operation of the latter [7]. In this study, organotherapics were chosen according to data in literature on dysfunctional brain areas in autism: corpus callosum [8,9]; thalamus [8,9]; hippocampus [8]; frontal lobe [10-12]; brain cortex [9]; cerebellum [9,11,12]; parietal lobe [12] and temporal lobe [8]. Organotherapics were used in dilution $6 \mathrm{cH}$.

\section{Results}

It is described the outcome of 7 of the 30 patients, who have already been tested twice for cognitivemotor performance, the first test applied before the onset and the second, 3-10 months after the onset of homeopathic treatment. (Table 1) Criteria for selection of remedies are described in Table 2.

DS: developmental scale (expected $=131)$. Autistic Behavior Intensity: A - adequate (expected score = 43); M - moderate; S - severe. EDA (estimate development age)

- In patient 01, behavioral improvement occurred especially in affect area, sensorial responses, play and interests in materials, as seen in Figure 1. In the developmental scale (DS), major progress concerned gross motor and eye-hand integration areas, followed by improvement in perception, imitation and cognitive performance, with consequent increase in the developmental profile (Figure 2).

- In patient 02 , improvement in behavior occurred in each profile area, of lesser intensity in sensorial responses, play and interest in materials (Figure 3). DS showed progress in fine motor and gross motor skills, followed by perception, imitation and cognitive performance, with consequent increase in the developmental profile (Figure 4).

- In patient 03, improvement in behavior occurred in play and interest in materials, sensorial responses and relationship and affect (Figure 5). DS showed improvement in imitation, perception and cognitive performance (Figure 6).

- In patient 04, improvements occurred mainly in sensorial response, relationship and affect and play and interest in materials (Figure 7). In the DS profile, improvements were significant in every area, especially in perception, cognitive performance and cognitive verbal, followed by imitation, fine and gross motor skills, eye-hand integration and development areas (Figure 8).

- In patient 05 , improvement in behavior occurred in the sensorial and language response areas (Figure 9). In DS profile, significant improvement occurred in perception, gross motor skills, cognitive performance, imitation, cognitive verbal, eye-hand integration. There was 1 point decrease in performance for fine motor skills coordination. (Figure 10)

- In patient 06, meaningful improvements took place in all areas, mainly communication, relationship and affect, sensorial responses, play and interest in materials (Figure 11). In DS 
profile, improvements occurred in all areas, especially in perception, eye-hand integration and cognitive performance. (Figure 12)
- In patient 07 , increase occurred in interaction and affect (Figure 13). DS showed the greatest improvement, encompassing all areas. (Figure 14)

Table 1. Scores of PEP-R in 7 autistic patients treated with homeopathy

\begin{tabular}{|c|c|c|c|}
\hline Patient & Treatment & $\begin{array}{l}\text { First application of } \\
\text { PEP-R }\end{array}$ & $\begin{array}{l}\text { Second application } \\
\text { of PEP-R }\end{array}$ \\
\hline $\begin{array}{l}\text { 01, male, } 4 \text { years } 8 \text { months } \\
\text { Second PEP-R at } 3 \text { months } \\
21 \text { days of treatment }\end{array}$ & $\begin{array}{l}\text { Arnica montana, } \\
200 \mathrm{cH}, \quad \text { weekly }+ \\
\text { compound } \\
\text { organotherapics } 6 \mathrm{cH} 3 \\
\text { times/day }\end{array}$ & $\begin{array}{l}\text { DS: } 27 \\
\text { ABI-A: } 15 \\
\text { ABI-M: } 7 \\
\text { ABI-S: } 23 \\
\text { EDA: } 15 \text { months }\end{array}$ & $\begin{array}{l}39 \\
15 \\
16 \\
13 \\
19 \text { months } \\
\end{array}$ \\
\hline $\begin{array}{l}\text { 02, male, } 10 \text { years, } 7 \\
\text { months } \\
\text { Second PEP-R at } 5 \text { months } \\
\text { of treatment }\end{array}$ & 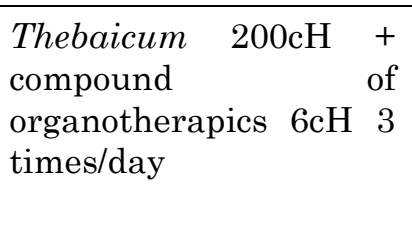 & $\begin{array}{l}\text { DS: } 17 \\
\text { ABI-A: } 8 \\
\text { ABI-M: } 21 \\
\text { ABI-S: } 14 \\
\text { EDA: } 12 \text { months }\end{array}$ & $\begin{array}{l}31 \\
15 \\
18 \\
10 \\
19 \text { months }\end{array}$ \\
\hline $\begin{array}{l}03, \text { male, } 14 \text { years } \\
\text { Second PEP-R at } 5 \text { months } \\
\text { of treatment }\end{array}$ & $\begin{array}{l}\text { Stramonium } 200 \mathrm{cH} \\
\text { weekly + compound of } \\
\text { organotherapics } 6 \mathrm{cH} 3 \\
\text { times/day }\end{array}$ & $\begin{array}{l}\text { DS: } 76 \\
\text { ABI-A: } 4 \\
\text { ABI-M: } 21 \\
\text { ABI-S: } 12 \\
\text { EDA: } 29 \text { months }\end{array}$ & $\begin{array}{l}80 \\
12 \\
29 \\
02 \\
35 \text { months } \\
\end{array}$ \\
\hline $\begin{array}{l}\text { 04, male, } 9 \text { years } \\
\text { Second PEP-R at } 6 \text { months } \\
\text { of treatment }\end{array}$ & $\begin{array}{l}\text { Arsenicum album } \\
200 \mathrm{cH}+\text { compound of } \\
\text { organotherapics } 6 \mathrm{cH} 3 \\
\text { times/day }\end{array}$ & $\begin{array}{l}\text { DS: } 35 \\
\text { ABI-A: } 06 \\
\text { ABI-M: } 22 \\
\text { ABI-S: } 14 \\
\text { EDA: } 16 \text { months }\end{array}$ & $\begin{array}{l}64 \\
16 \\
14 \\
13 \\
28 \text { months }\end{array}$ \\
\hline $\begin{array}{l}05, \text { male, } 6 \text { years } \\
\text { Second PEP-R at } 6 \text { months } \\
\text { of treatment }\end{array}$ & $\begin{array}{lr}\text { Carcinosinum } & 200 \mathrm{cH}+ \\
\text { compound } & \text { of } \\
\text { organotherapics } & 6 \mathrm{cH} \quad 3 \\
\text { times/day } & \end{array}$ & $\begin{array}{l}\text { DS: } 95 \\
\text { ABI-A: } 35 \\
\text { ABI-M: } 05 \\
\text { ABI-S: } 03 \\
\text { EDA: } 42 \text { months }\end{array}$ & $\begin{array}{l}105 \\
38 \\
00 \\
05 \\
48 \text { months } \\
\end{array}$ \\
\hline $\begin{array}{l}\text { 06, female, } 3 \text { years } 5 \\
\text { months } \\
\text { Second PEP-R at } 6 \text { months } \\
\text { of treatment }\end{array}$ & 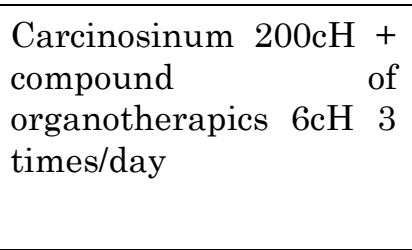 & $\begin{array}{l}\text { DS: } 36 \\
\text { ABI-A: } 16 \\
\text { ABI-M: } 20 \\
\text { ABI-S: } 07 \\
\text { EDA: } 18 \text { months }\end{array}$ & $\begin{array}{l}62 \\
38 \\
05 \\
00 \\
24 \text { months }\end{array}$ \\
\hline $\begin{array}{l}\text { 07, male, } 4 \text { years } 4 \text { months } \\
\text { Second PEP-R at } 10 \\
\text { months of treatment }\end{array}$ & $\begin{array}{l}\text { Natrium muriaticum } \\
200 \mathrm{cH}+\text { compound of } \\
\text { organotherapics } 6 \mathrm{cH} 3 \\
\text { times/day }\end{array}$ & $\begin{array}{l}\text { DS: } 58 \\
\text { ABI-A: } 25 \\
\text { ABI-M: } 14 \\
\text { ABI-S: } 04 \\
\text { EDA: } 24 \text { months }\end{array}$ & $\begin{array}{l}87 \\
26 \\
14 \\
03 \\
37 \text { months }\end{array}$ \\
\hline
\end{tabular}

Table 2. Criteria for selection of remedies 


\begin{tabular}{|c|c|c|}
\hline Patient 1 & Remedy & Symptoms \\
\hline 01 & Arnica montana & $\begin{array}{l}\text { Hypersensitiveness to all } \\
\text { external impressions; } \\
\text { Sensitiveness to touch; } \\
\text { Startling by fright; Startling in } \\
\text { the night; Severe attacks of } \\
\text { anxiety; Stubborn resistance; } \\
\text { Fear of strangers coming near } \\
\text { for fear of being touched; } \\
\text { Capriciousness }\end{array}$ \\
\hline 02 & Thebaicum & $\begin{array}{l}\text { Fear; Insensitiveness to pain; } \\
\text { Mental alienation; } \\
\text { Loquaciousness; } \\
\text { Hypersensitiveness to noise; } \\
\text { Changing mood; Chronic } \\
\text { constipation }\end{array}$ \\
\hline 03 & Stramonium & 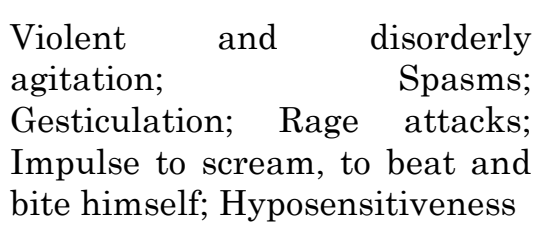 \\
\hline 04 & Arsenicum album & $\begin{array}{l}\text { Extreme anxiety; Dictatorial; } \\
\text { Bites himself; Always holding } \\
\text { the mother's hand; Desire to } \\
\text { climb; Impatience; Chronic } \\
\text { constipation; Cutting hair } \\
\text { aggravates }\end{array}$ \\
\hline 05 & Carcinosinum & $\begin{array}{lr}\text { Full of cares; Perfectionism; } & \text { Extreme } \\
\text { perseverance; } & \text { Ext } \\
\text { affectivity; Sadness; } & \text { Enraged } \\
\text { with own } & \text { mistakes; } \\
\text { Hypersensitiveness to music }\end{array}$ \\
\hline 06 & Carcinosinum & $\begin{array}{l}\text { Extreme affectivity; Intense } \\
\text { control of affect; Fastidiousness; } \\
\text { Stubbornness; Timidity; Love } \\
\text { for music; Dancing; Tics }\end{array}$ \\
\hline 07 & Natrium muriaticum & $\begin{array}{l}\text { Desire for solitude; Indifference } \\
\text { in society; Quiet and } \\
\text { melancholic disposition; } \\
\text { Aversion to answer and to talk; } \\
\text { Easily crying; Consolation agg.; } \\
\text { Causeless laughter; } \\
\text { Concentration difficult; Delayed } \\
\text { development; Anxiety and } \\
\text { agitation, alternating with } \\
\text { indifference. }\end{array}$ \\
\hline
\end{tabular}

Figure 1: Patient 01: Behavior

Figure 2: Patient 02: Developmental scale 

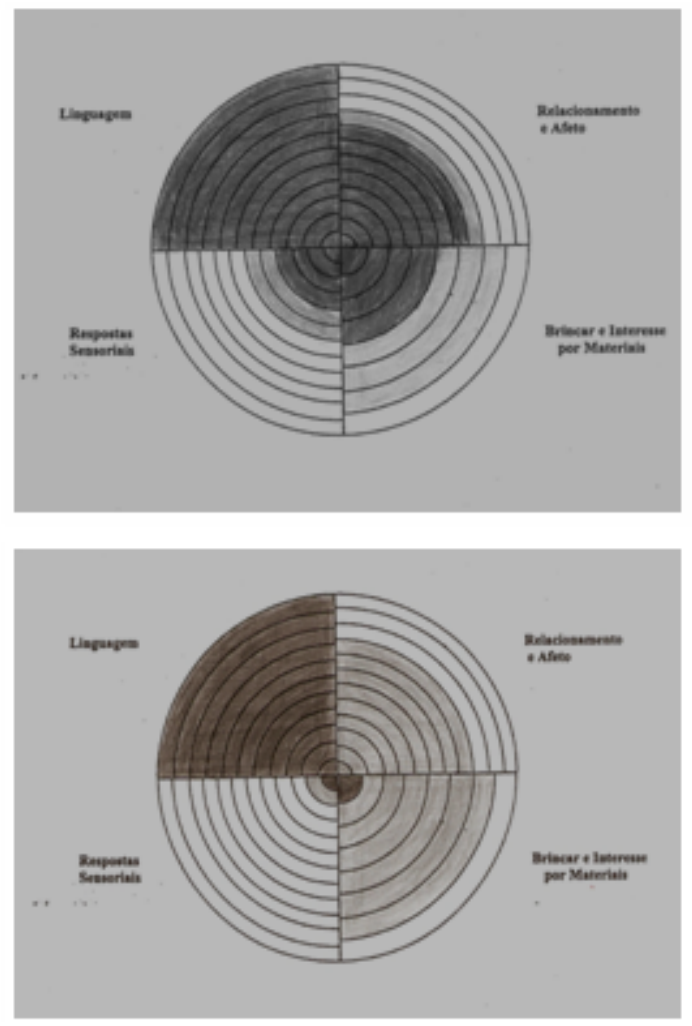

Figure 3: Patient 02: Behavior
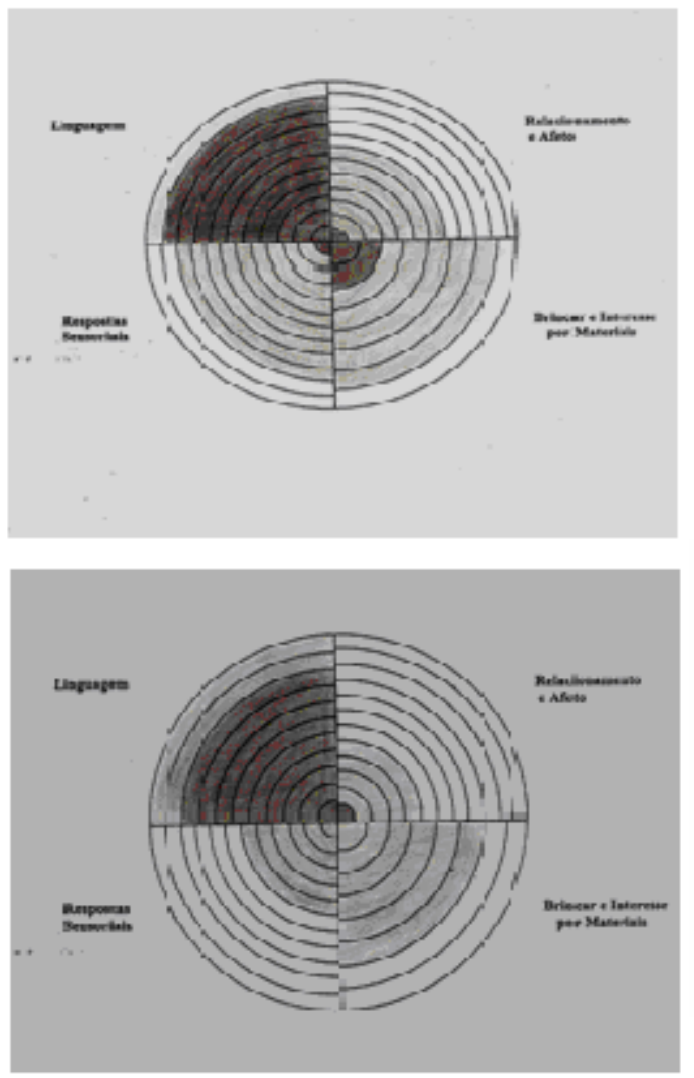

Figure 5: Patient 03: Behavior

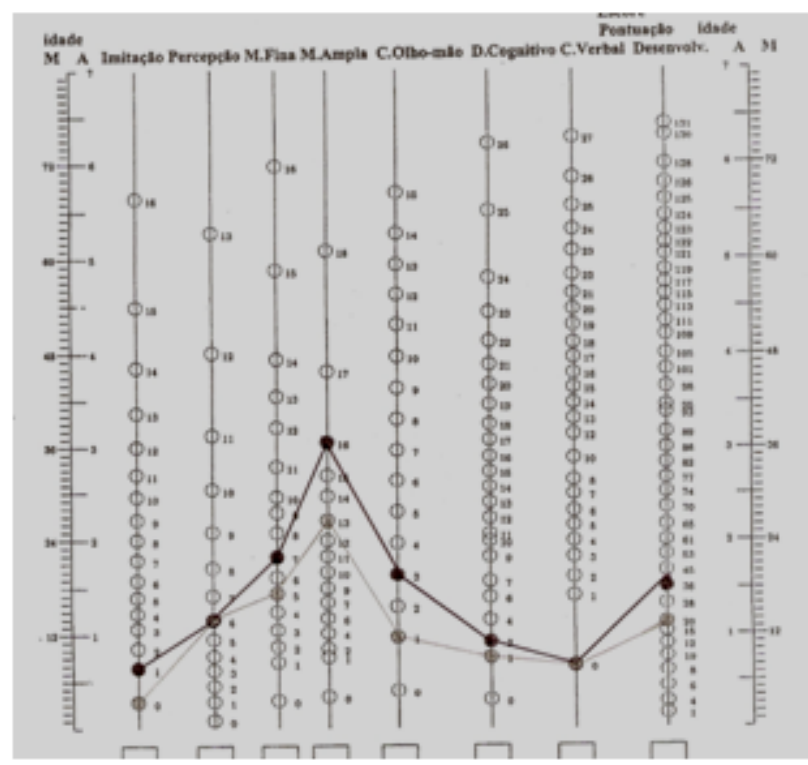

Figure 4: Patient 02: Developmental scale

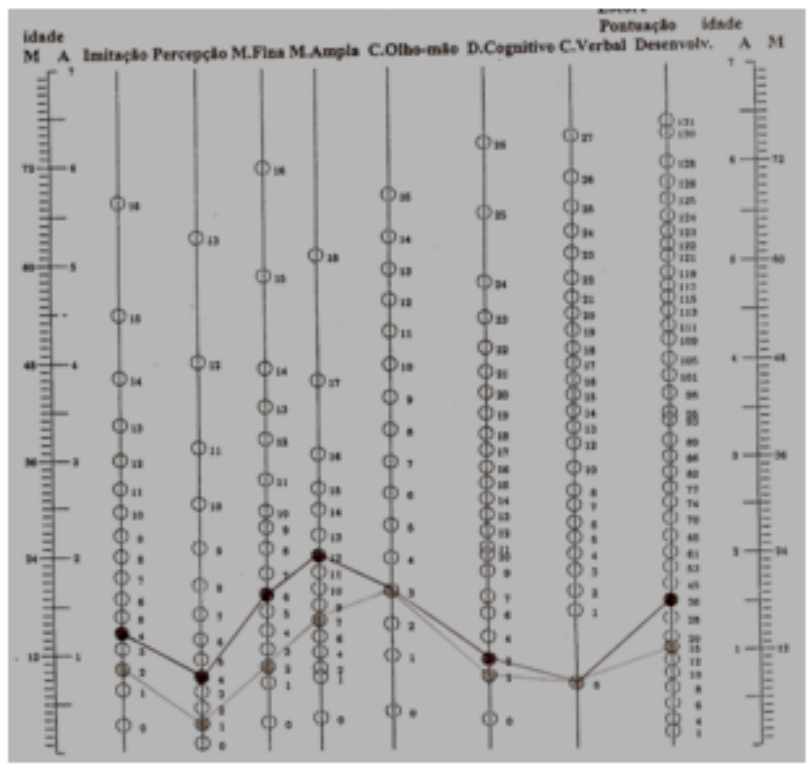



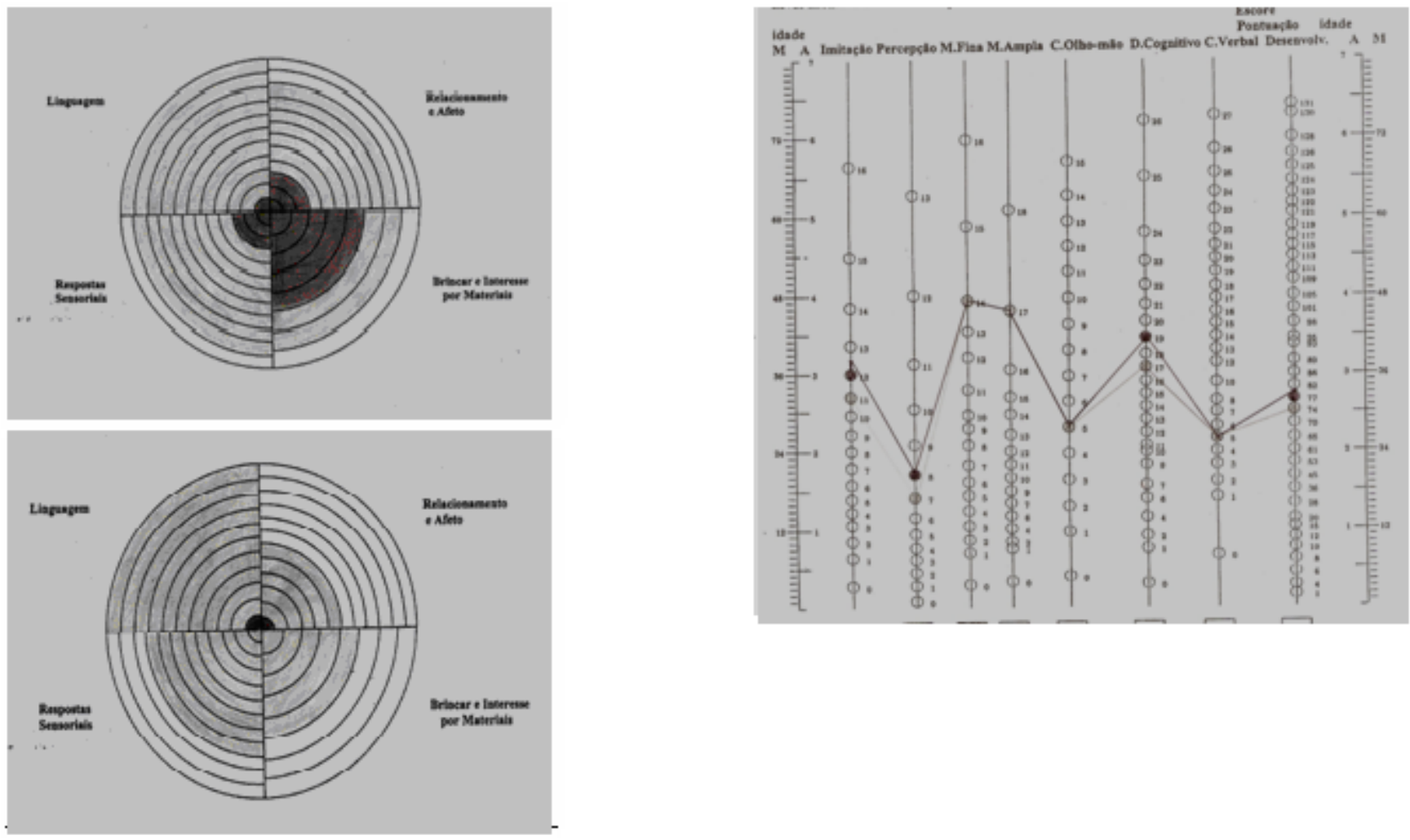

Figure 7: Patient 04: Behavior
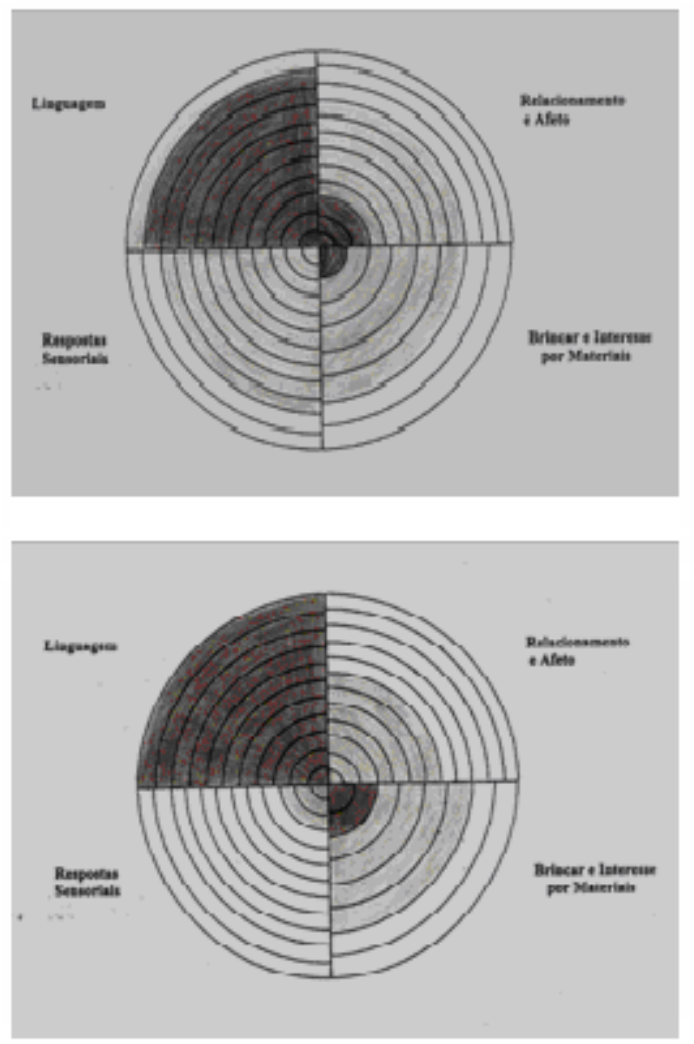

Figure 08: Developmental scale

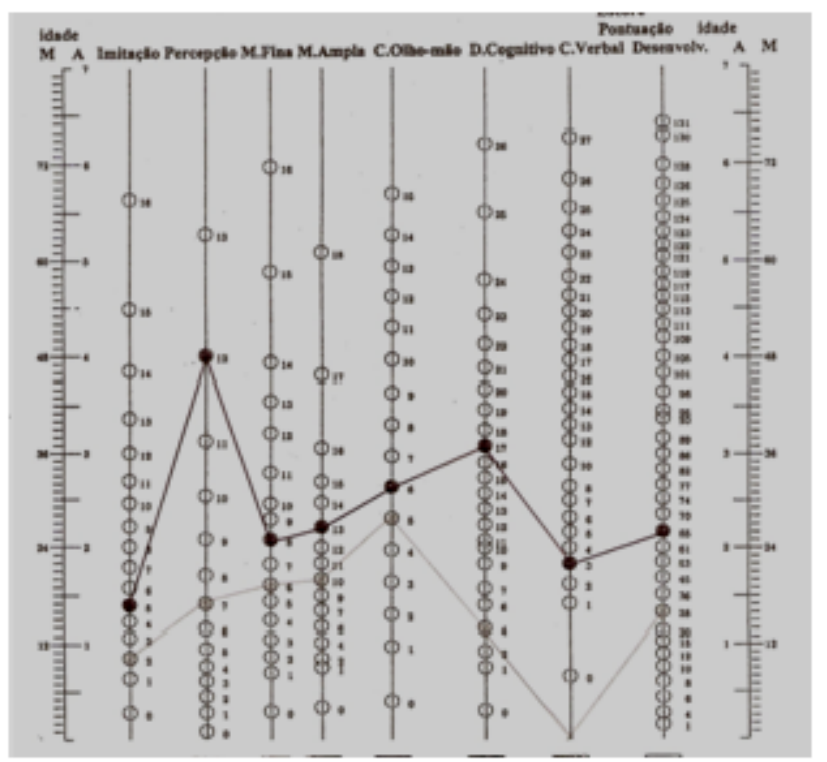



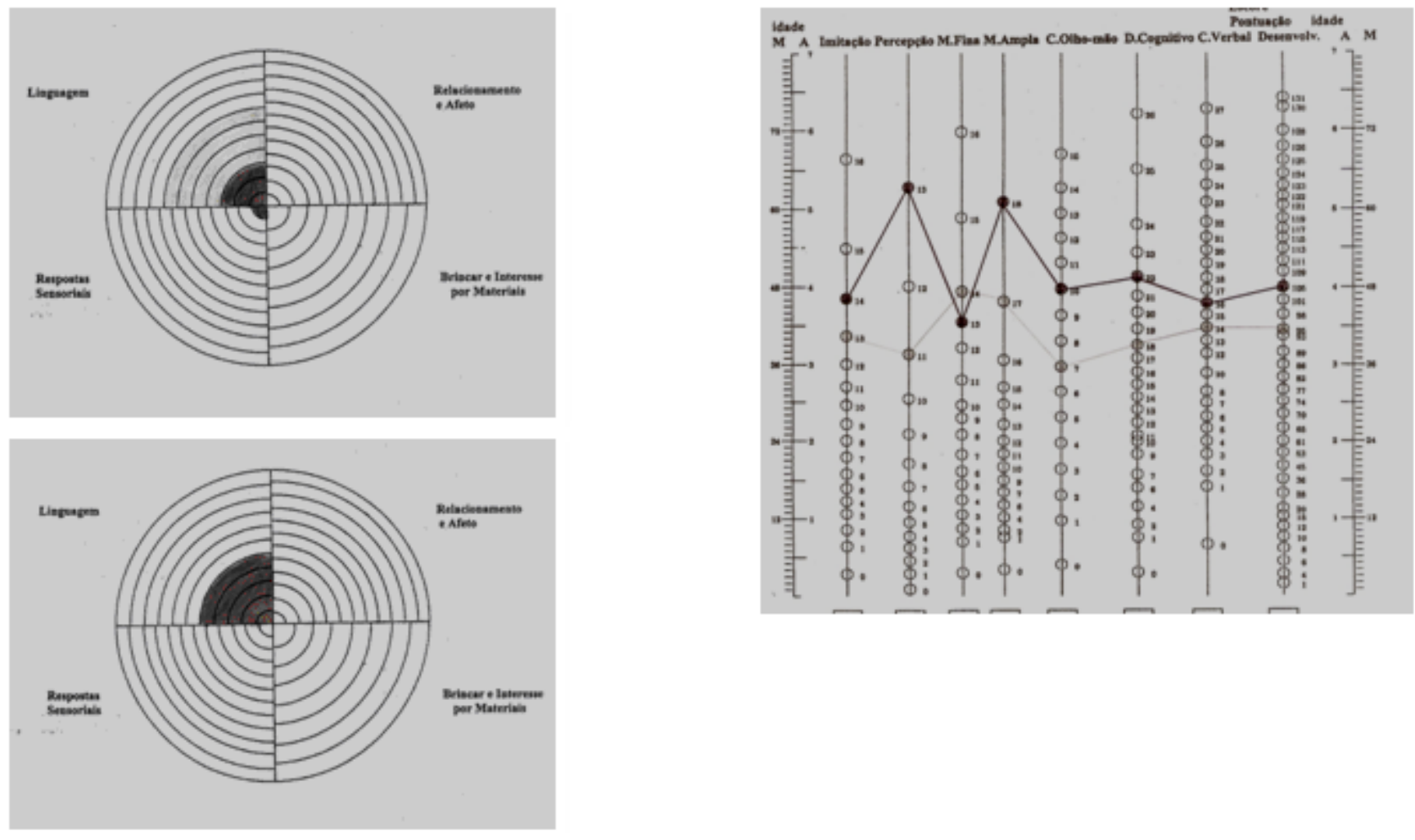

Figure 11: Patient 06: Behavior
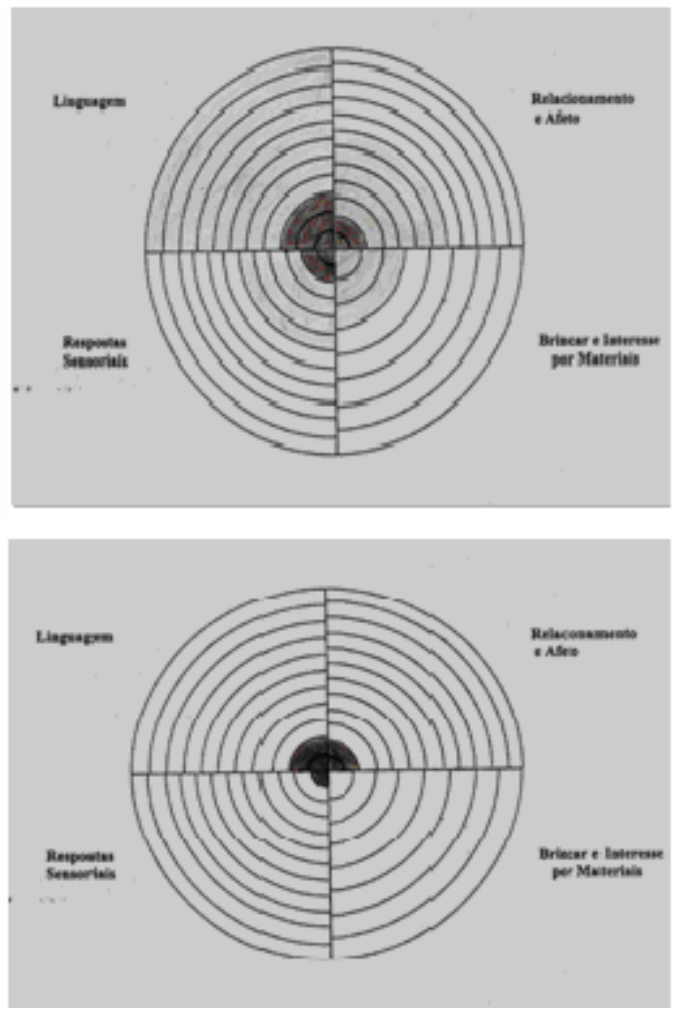

Figure 12: Patient 06: Developmental scale

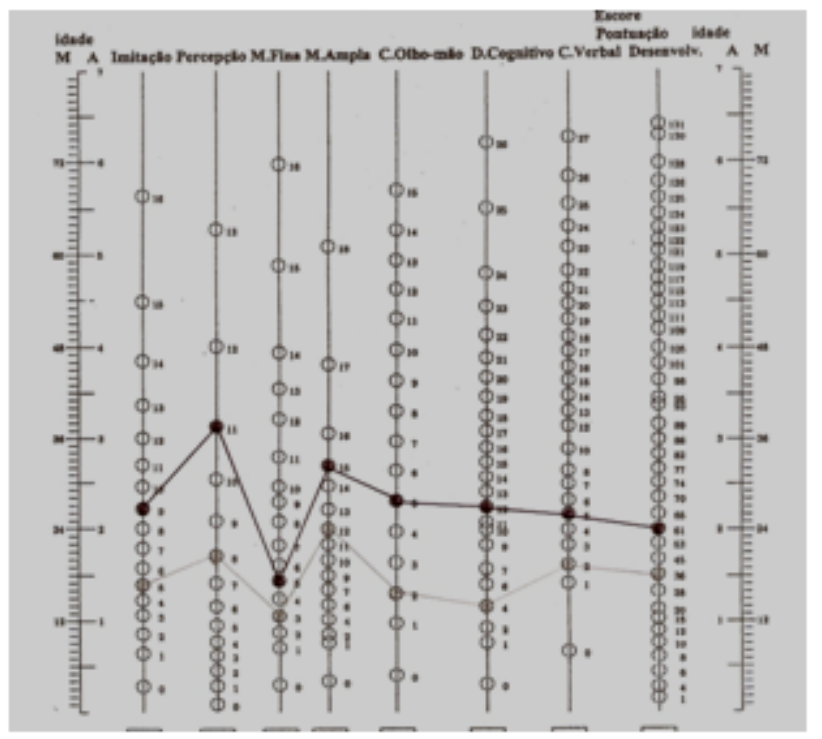

Figure 13: Patient 07:Behavior

Figure 14: Patient 07: Developmental scale 

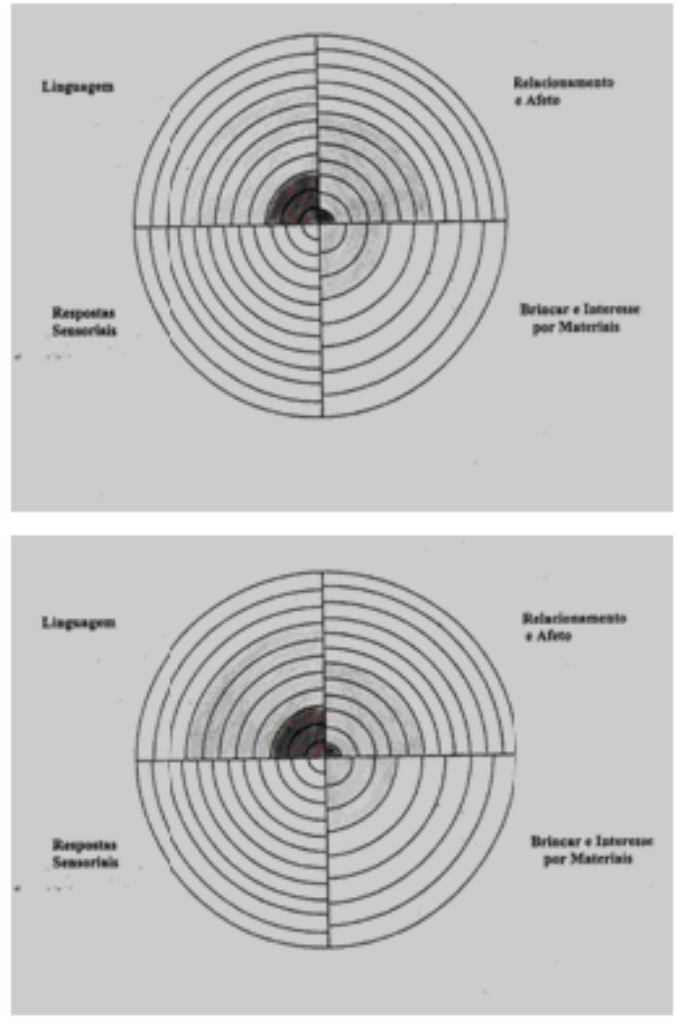

\section{Conclusion}

Analysis of these partial data show the positive interference of homeopathic treatment in the cognitive, motor and behavioral performance of autistic patients. These results also suggest that the longer the use of the medication, the more remarkable the improvement in PEP-R scores. Similarly, the earlier the onset of treatment, the more remarkable the outcome. On the other, even in teenagers, homeopathic treatment positively affected behavior, with a decrease in aberrant behavior and better social and familiar integration.

These preliminary results encourage our research group to perform a study with a larger population, to be followed by a randomized controlled doubleblind trial, while preserving all the specificities of the homeopathic approach.

\section{References:}

[1] Autisme-Europe. Bruxelles: Autisme-Europe; 2006-. [updated 2008 jan; cited 2008 jan]. Available from: http://www.autismeurope.org.

[2] Organização Mundial da Saúde. Classificação Estatística Internacional de Doenças e Problemas Relacionados à Saúde - CID-10. $10^{\text {a }}$ revisão. São Paulo: OMS; 2000.

[3] Associação Americana de Psiquiatria. Manual Diagnóstico e Estatístico de Transtornos Mentais DSM-IV. Porto Alegre: Artes Médicas; 2002.

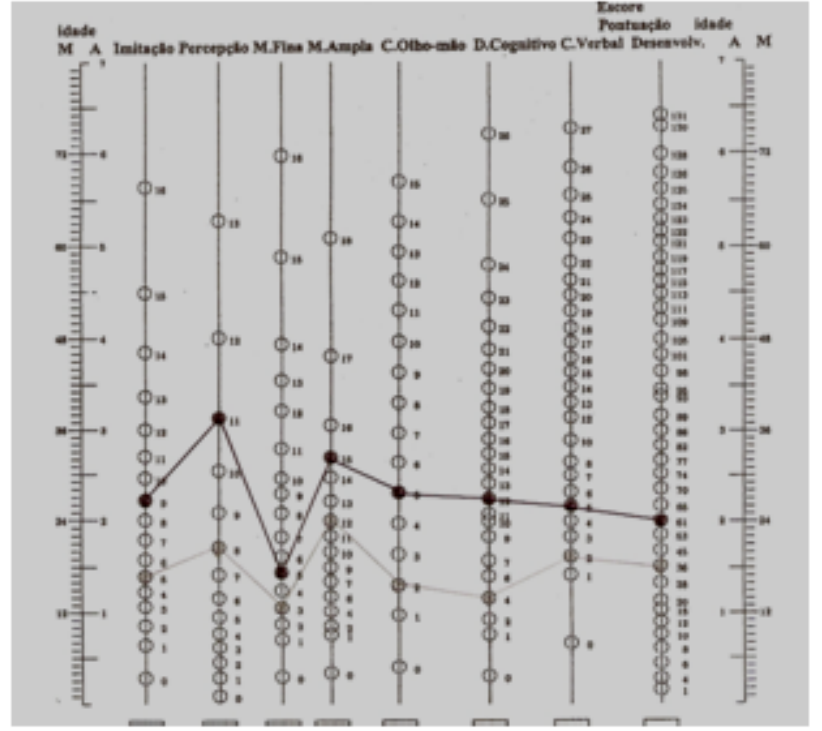

[4] Schopler E, Reichler RJ. Individualized assessment of autistic and developmentally disabled children. Psychoeducational Profile (PEP). Vol 11. Austin: PRO-ED; 1979.

[5] Schopler E, Lansing M, Waters L. Individual assessment and treatment for autistic and developmentally disabled children. Teaching activities for autistic children. Vol 13. Austin: PROED; 1983.

[6] Schopler E, Reichler RJ, Renner B. The Childhood Autism Rating Scale (CARS). Los Angeles (CA): Western Psychological Services. U.S. Bureau of the Census. Statistical Abstract of the U.S./Washington DC: Government Printing Office; 1985.

[7] Tetau M. Homeopatia e estruturas bioterápicas. $6^{\mathrm{a}}$ ed. São Paulo: Andrei; 1980.

[8] Ito H, Mori K, Hashimoto T, Miyazaki M, Hori A, Kagami S, et al. Findings of brain $99 \mathrm{mTc}-\mathrm{ECD}$ SPECT in high-functioning-autism-3-dimensional stereotactic ROI template analysis of brain SPECT. J Med Invest. 2005; 52(1-2): 49-56.

[9] Nicolson R, Szatmari P. Genetic and neurodevelopmental influences in autistic disorder. Can J Psychiatry. 2003; 48(8): 526-537.

[10] Courchesne E, Pierce K. Why the frontal cortex in autism might be talking only to itself: local overconnectivity but long-distance. Curr Opin Neurobiol. 2005; 15(2): 225-230. 
[11] Haist F, Adamo M, Westerfield M, Courchesne $\mathrm{E}$, Townsend J. The functional neuroanatomy of spatial attention in autism spectrum disorder. Dev Neuropsychol. 2005; 27(3): 425-458.

[12] Laurence JA, Fatemi SH. Glial fibrillary acidic protein is elevated in superior frontal, parietal and cerebellar cortices of autistic subjects. Cerebellum. 2005; 4(3): 206-210.

[13] Muller RA, Kleinhans N, Kemmotsu N, Pierce $\mathrm{K}$, Courchesne E. Abnormal variability and distribution of functional maps in autism: an FMRI study of visuomotor learning. Am J Psychiatry. 2003; 160(10): 1847-1862.

\section{(c)) BY-No-ND Licensed to GIRI}

Support: authors declare that this study received no funding

Conflict of interest: authors declare there is no conflict of interest

Revised 21 June 2008; Published: 30 June 2008

Revised version of presentation at 63rd Congress of LMHI, Oostende, May 20-24th, 2008

Erratum: 30 Dec 2008. (http://www.feg.unesp.br/ ojs/zacha ijhdr/erratum/?v=7\&i=23\&pi=63)

Correspondence author: Geórgia Regina Macedo de Meneses Fonseca. georgiaregina@globo.com

How to cite this article: Fonseca GRMM, Bolognani FA, Durão FF, Souza KM, Accioly MCC, Bagarollo, MF. Effect of homoepathic medication on the congnitive and motor performance of autistic children (pilot study). Int J High Dilution Res [online]. 2008 [cited YYYY Mmm DD]; 7(23) 63-71. Available from:

http://www.feg.unesp.br/ ojs/index.php/ijhdr/article/view/285/353. 